S. I. CONCILIAR TRINITARIANISM

DOI: https://doi.org/10.14428/thl.v4i2.22113

\title{
On the Economic Focus of Conciliar Trinitarianism
}

\author{
DECLAN O'BYRNE
}

Sophia University Institute

declan.obyrne@sophiauniversity.org

\begin{abstract}
This article suggests that the shape of Conciliar Trinitarianism is rather different to what is often supposed in recent theological treatments of the Trinity. Conciliar Trinitarianism does support the claims of the consubstantiality of the Son and the full divinity of the Spirit, but is not directly concerned with a doctrine of One God in three persons in abstraction from the economy of salvation. The economy (oikovo $\mu$ í $\alpha$ ) is not taken as the starting point for knowledge of the "immanent Trinity". Instead, claims about Trinity in itself ground claims about the economy of salvation.
\end{abstract}

Keywords: Ecumenical Councils; Trinity; Incarnation; One God; Revelation

\section{Introduction: Pawl's Criteria and Conciliar Trinitarianism}

Timothy Pawl's recent book on "Conciliar Christology" (Pawl 2016) aims at an exploration of the key teachings of the first seven ecumenical councils with regard to the "doctrine of the incarnation". Conciliar Christology, he says, is "the conjunction of all the claims made at these councils concerning the doctrine of the incarnation." (Pawl 2016, 1) He clarifies the motivations leading to his choice of these seven ecumenical councils, rather than a larger or smaller set of magisterial statements, by pointing out that in this way he can speak of the faith of the great majority of Christians: "Thus, the largest conjunction of ecumenical, christological claims that traditionally receives special status in both the eastern and western traditions is the conjunction that comes from these seven councils." (Pawl 2016, 1) In executing this decision, however, he does not confine himself to any one genre of conciliar document, opting instead to consider all forms of documentation approved by these seven councils, including documents approved by though not composed by those councils.

The conjuncts of this conjunction come from definitions and expositions of faith, creeds, canons, and anathemas of the councils. If such conciliar statements 


\section{DECLAN JOSEPH O'BYRNE}

include other documents - for example, as Chalcedon's Definition of the Faith accepts Cyril's second letter to Nestorius and his letter to John of Antioch, as well as Leo's Tome to Flavian (Tanner 1990, 85) - then I will include the Christological teachings from those documents as conjuncts of Conciliar Christology, too. (Pawl $2016,12)$

His generosity in this sense stretches, for example, to Cyril's Third Letter to Nestorius, including its 12 Anathemas, because although this letter may not have been accepted by the Council of 431, it clearly was by the Council of 553 (Pawl 2016, 12-13).

On the other hand, Pawl chooses not to take later Latin councils into consideration. To do so would, in his view, weaken the catholicity of the conciliar christology that he intends to consider. He wishes to take into consideration the "creeds, canons, expositions of faith, and anathemas, as well as any documents accepted and endorsed in the previously listed sources" (Pawl 2016, 3). He chooses not to appeal to scripture or the fathers in order to justify the truth of conciliar christology, since it is not his intention to prove the truth of the doctrine, but to examine the teachings of these councils, responding to logical and philosophical point of view to difficulties that the doctrine of the Incarnation raises (Pawl 2016, 4). On this basis. Pawl begins his enquiry by setting out, in his first chapter, the key teachings of conciliar christology. In his estimation, these teachings may be schematically set out as follows:

(i) there was (and is) one person, Jesus Christ, the Second Person of the Holy Trinity, who, after the incarnation, has two complete and distinct natures. One of these natures is (ii) the one and only divine nature. The other nature is (iii) a fully human nature. These natures were (iv) combined in a unique mode of union, called the "hypostatic union." In virtue of this union, (v) predications are true of Jesus Christ according to each nature. (Pawl 2016,14)

The current article will argue that if one applies Pawl's criteria to a similarly conceived reconstruction of Conciliar Trinitarianism, the shape of trinitarian reflection emerging will be rather different to the trinitarianism that draws on later church teachings together with the teachings of the patristic and scholastic authorities of the classical tradition. We will see that the ecumenical councils ${ }^{1}$ do

\footnotetext{
${ }^{1}$ It is important to note that in this essay, I use the expression "ecumenical councils" to indicate the first 7 ecumenical councils, following Pawl's usage. I set aside the thorny question of the ecumenical nature of later councils said to be "ecumenical". I do not deny that these might also be defended as ecumenical. It might be safe, however, to suggest that the ecumenical character of
} 
not appear to directly support many of the claims that trinitarian theology takes for granted and argue that this is of direct interest to any attempt to discuss the contours of a Conciliar Trinitarianism.

The crucial question is: what is "trinitarianism"? This word might mean something quite general like "everything and anything to do with the doctrine that the God of Christianity is One God in three persons". More specifically, it might mean adhesion to that doctrine such that "trinitarianism" might be contrasted with unitarianism, modalism or tritheism. In either case, the existence of a doctrine of the Trinity is presupposed. What is this doctrine, and is it found in the teaching of the ecumenical councils?

These might seem to be idle questions; I will argue that they are not. Indeed, if we give what appears to be the obvious answer to the first question, we will find that we will have to answer the second question negatively. The apparently obvious answer to the first question is that the doctrine of the Trinity is the doctrine that there is One God in three persons, namely the Father, the Son and the Holy Spirit. Let us call this summary DT1. Yet, if we confine ourselves to Pawl's criteria we find that this doctrine is not explicitly stated anywhere in Conciliar Trinitarianism. Instead, what we find in Conciliar Trinitarianism might be summarized as follows: there is One God, the Father, and that the Son and the Holy Spirit share in the divinity of the One God in a non-subordinationist way such that the Trinity of Father, Son and Holy Spirit are all rightly called God and together work in the economy of salvation, culminating in the Incarnation of the

later councils is less than fully manifest when produced in a context of church division. Pawl's motivation is to speak of the faith of the majority of Christians. A question I would raise is whether there might be some analogy between the relation of scripture to the doctrine of these 7 ecumenical councils, and the relation of these 7 ecumenical councils to later ecumenical councils of the Latin tradition. Scripture does not make explicit every dimension of the Christian faith, and neither do the first 7 ecumenical councils. Nevertheless, scripture does have a kind of primacy such that the dogmas expressed in the first ecumenical councils are rooted in scripture. I see no reason why a distinction between the teaching of these ecumenical councils should be taken as ruling out the ecumenical quality of later councils. Nevertheless, the first 7 might be thought to have a kind of primacy with respect to the later councils. The question is not simply a question of ecclesiology. It is perhaps also a question of how the Holy Spirit has accompanied the church's unfolding understanding of the Christian faith. The words of Dei Verbum 8 seem apposite here: "For there is a growth in the understanding of the realities and the words which have been handed down. This happens through the contemplation and study made by believers, who treasure these things in their hearts (see Luke, 2:19,51) through a penetrating understanding of the spiritual realities which they experience, and through the preaching of those who have received through Episcopal succession the sure gift of truth. For as the centuries succeed one another, the Church constantly moves forward toward the fullness of divine truth until the words of God reach their complete fulfilment in her." 


\section{DECLAN JOSEPH O'BYRNE}

Son and the outpouring of the Holy Spirit. Let us call this summary DT2.

Within the confines of this short article I can do no more than present a preliminary argument for the claim that DT1 is not an accurate summary of Conciliar Trinitarianism, and the claim that DT2 is a more promising starting point. I will conclude with some comments on the ways in which DT2 relates claims about the economy of salvation to claims about the Trinity apart from the economy of salvation.

\section{DT1 and Conciliar Trinitarianism}

DT1 - the commonly assumed understanding of the doctrine of the Trinity states that there is One God in three persons, the Father, the Son and the Holy Spirit. This extreme summary might be expanded to include other claims. A helpful overview of such claims is set out in the introduction to Chapter 3 of Neuner-Dupuis' The Christian Faith in the Doctrinal Documents of the Catholic Church (2001). The editors of this book, obviously, do not attempt to work within the confines of Pawl's criteria, and are therefore not mistaken in attributing many of the claims for the doctrine of the Trinity to official Catholic Church teaching. However, if one does assume Pawl's criteria, one sees how many of the points of teaching that they include in their summary are not part of Conciliar Trinitarianism. I take Neuner-Dupuis' list of doctrinal points on the Triune God as one example of what contemporary theology takes as the doctrine of the Trinity (DT1), and in my comments I seek to show how the claims of DT1 fall largely outside the scope of the teaching of the ecumenical councils. In the following section, I will attempt to indicate how DT2 is a better summary of the teaching of Conciliar Trinitarianism.

One should immediately note that the title of chapter 3 of this book, "The Triune God", already shows that their summary will reach beyond the contents of Conciliar Trinitarianism, since strictly speaking God is not said to be Triune in the ecumenical councils. While the ecumenical councils do defend the full divinity of the Son and the Holy Spirit, such that each of them is rightly said to be God, it is not automatically true that the Trinity is also God. The editors of Neuner-Dupuis, in contrast, assume throughout their list of teaching points that the word God is to be understood as meaning the whole Trinity.

The first of the teaching points they list is as follows: "There is one personal God". In support of this claim, they list The Symbol of the Roman Order of Baptism, The Symbol of Eusebius, The Symbol of Nicaea, The Symbol of Cyril of Jerusalem, The Symbol of Epiphanius, The Symbol of Constantinople, The Faith of Damasus. They also list texts from Lateran IV, the Creed of Paul VI, the Tome 
of Damasus ${ }^{2}$ and Dei Filius of the First Vatican Council. If we choose from this list the documents approved by the ecumenical councils, namely the Symbols of Nicaea (325) and Constantinople (381), we do of course find that there is one God, who is clearly personal. But it is not stated in these Symbols that the "one God" in question in the Trinity. In these texts it is directly stated that the One God is the Father, Almighty.

Since there is no other text of the ecumenical councils that states that the One God is the Trinity, we must take the teaching that the One God is the Father as a key point of Conciliar Trinitarianism. Neuner-Dupuis, however, not bound by Pawl's criteria, assume that the word God simply means the Trinity in the teaching point- "In God there are three persons, Father, Son, and Holy Spirit". The documents listed in favour of this second point are ND 1-19 (all of the symbols and professions of faith, including those of Nicaea and Constantinople I), and then-once again-Lateran IV, Paul VI, then the Letter of Dionysius to Dionysius of Alexandria (262), the Tome of Damasus (382), the Council of Toledo (675), and the Decree for the Copts of the Council of Florence (1442). Again, if we look only to the documents considered as sources of Conciliar Trinitarianism, we do not find any statement that there are three persons in God. Instead, we find that there is One God, the Father, the Son of God who is "true God from true God" and consubstantial with the Father, and the Holy Spirit who proceeds from the Father, and is rightly worshipped with the Father and the Son. In their listing of magisterial sources, they give the impression that the Christian faith, from the earliest times, manifests a stable doctrine in an idea of God who is one, but who is also three persons. Attention to strictly defined Conciliar Trinitarianism, instead, reveals a development in the use of God language, with the idea of One God in three persons appearing only in later magisterial texts.

The assumption that the One God simply is the Trinity is, of course, far from uncommon. Indeed, since many assume that the doctrine of the Trinity is the doctrine of One God in three persons, any claim otherwise might appear to be incompatible with the doctrine of the Trinity. We should not be alarmed, however. The ecumenical councils certainly do proclaim the Trinity. To proclaim the Trinity, however, is not the same as stating that the One God is the Trinity. In its simple form, found in the Symbols of Nicaea and Constantinople, it is the proclamation of belief in God (the Father), in the Son of God and in the Holy Spirit, each of who is fully divine. Conciliar Trinitarianism is also against any modalist reduction of the three to one, such that to proclaim the Trinity is to

\footnotetext{
2 The reader is left to wonder at meaning of the chronologically curious sequence: Paul VI, Tome of Damasus, Vatican I.
} 
proclaim the eternal distinction of the three. This is stated, for example, in the rejection of what was taken as the implicit modalism in the theology of Marcellus of Ancyra, and formulated in the expression of the Symbol of Constantinople (381): "His kingdom will have no end". The proclamation of God, the Son of God and the Holy Spirit, and the denial of modalism, however, does not mean that the One God is the Father, Son and Holy Spirit, and the ecumenical councils nowhere use the term "One God" to refer to the Trinity.

The Conciliar teaching of the Trinity, however, is more than simply the teaching that there is One God (the Father) and there is the Son of God and the Holy Spirit. It is also the claim that each of them is properly said to be divine, and that neither the Son nor the Spirit should be said to be one of the creatures. Thus, it can be said that all three of them are "God"; though each in a different sense. The Father is the One God, the Son is the Son of God, consubstantial with the Father, and the Holy Spirit proceeds from the One God. The Symbol of Nicaea uses the language of consubstantiality as its primary way of expressing the true divinity of the Son. The Council of Constantinople (381), faced with subordinationist tendencies with regard to the Holy Spirit, does not use this same language to speak of the true divinity of the Holy Spirit, but rather of fact that the Holy Spirit is "worshipped and glorified with the Father and the Son". In context, this is to be taken as a clear statement of the non-subordination of the Spirit, since no creature should be worshipped alongside the Father and the Son. Clearly, the fact that the expression "One God" is reserved to the Father is not to be taken in such a way that the Son and the Holy Spirit are among the creatures.

Returning to Neuner-Dupuis' list of teaching points: the editors then offer us a number of points that are grouped under the heading "One God, three persons". We have just seen that the first three points were listed under the heading "The Christian concept of God", and the most relevant of these for our purposes was that there is "one personal God". It now appears that this one personal God is the Trinity, and-presumably-is "personal" because it is composed (so to speak) of three "persons". There are several points listed under the heading "One God, three persons". These are that "in God there are three persons, Father, Son and Holy Spirit"; that the "three are one undivided Godhead"; that "each person is fully God" with three sub-points-that the Father is fully God, that the Son is fully God and that the Holy Spirit is fully God-; that the "divine persons are distinct from one another"; and, finally, that they "are distinct through mutual relationship."

A number of comments are called for here. The first relates to the doctrinal point that "in God there are three persons". Among the texts quoted in support of this idea we find the symbols of Nicaea and Constantinople, so at first sight it appears that we have direct and complete support here for DT1. If we accept this point and combine it with the heading "One God, three persons", one quickly 
arrives at popular summary of the doctrine of the Trinity itself: "one God in three persons". Unfortunately, however, for a Conciliar Trinitarianism that follows Pawl's criteria, we do not find this teaching in either Nicaea or Constantinople, at least not with the neat formula that the summary suggests.

Problems arise with all parts of the formula, not just with the expression "One God", which - as we have seen - refers to the Father and not to the whole Trinity, but also with the expression "three persons", as well as with the somewhat vague "in" that the popular formula uses to link "One God" with "three persons". With regard to the use of the term "person", it is worthy of note that it is not used in either of the Symbols of the Faith. Indeed, if we examine the texts that NeunerDupuis quote in support of this doctrinal point, we see that the Letter of Dionysius of Rome to Dionysius of Alexandria (262) uses the term hypostasis only in order to characterize a position to be excluded as compromising the monarchia: "they somehow preach three gods as they divide the sacred unity into three different beings (hupostaseis), entirely separate from each other" (ND 301). To state this is simply to point out that whatever the use of that letter means, this text, which in any case would not be considered a source for Conciliar Trinitarianism, cannot be used to support the language of three persons. More relevant is the citation of the Tome of Damasus (382), which embraces the term persona more than a century later: "Anyone who denies that there are three true persons, the Father, the Son and the Holy Spirit, equal, living eternally, containing all things visible and invisible, all powerful, judging, creating and saving all things, is a heretic" (ND 306/21). Unfortunately, the latter text would not be invoked in a Conciliar Trinitarianism that follows Pawl's criteria.

Entirely missing, instead, from Neuner-Dupuis' list of authorities in favour of the idea of there being three persons is the primary conciliar text that uses the language of persons to indicate the Father, the Son and the Holy Spirit, namely the first canon from the Second Council of Constantinople (553). This text reads, in the translation found in Neuner-Dupuis:

If anyone does not confess that Father, Son and Holy Spirit, are one nature (phusis) or essence (ousia), one might and power, a Trinity one in being (homoousios), one Godhead to be worshipped in three hypostases or persons (prosopon), anathema sit. For one is the God and Father from whom all things are, one is the Lord Jesus Christ through whom all things are and one the Holy Spirit in whom all things are. (ND 620/1)

Here is a conciliar text, acceptable on Pawl's criteria, that uses the language of three hypostases. This text, however, is not quoted by Neuner-Dupuis in favour of their doctrinal point that there is one God in three persons. As far as I can tell, if by "trinitarian" we mean a focus on the doctrine of the Trinity in se, this is the most "trinitarian" of conciliar texts. Notwithstanding this, this canon of the 


\section{DECLAN JOSEPH O'BYRNE}

Council of 553 is found in Neuner-Dupuis, not in the chapter on the Triune God, but in the sixth chapter, on Jesus Christ the Saviour.

This text, however, does not contradict what has been said above about the One God being the Father. On the crucial point, the Greek text does not speak of "one God" ("vv $\theta \varepsilon \dot{v} v$ ) as in first line of the symbols of Nicaea and Constantinople, but only of " $\mu$ í $\alpha \nu \theta \varepsilon o ́ \tau \eta \tau \alpha$ ", which can be translated "one divinity" or "one Deity" or divinity rather than one God. Indeed, the canon goes on to quote 1 Cor 8:6 where Paul is quite clear that the one God is the Father.

It is worth comparing this canon of 553 with a text of the Lateran Council (649) which, though similar in many ways, uses the expression "one God" in a new way, which then becomes standard in the Latin tradition, to indicate the whole Trinity:

If anyone does not, according to the holy Fathers, confess truly and properly the Father and the Son and the Holy Spirit, Trinity in unity and unity in Trinity, that is, one God in three consubstantial hypostases equal in glory; and for the three one and the same Godhead, nature, essence (ousia), power, Lordship, kingship, authority, will, action (energeia) and sovereignty; uncreated, without beginning, infinite, immutable, creator of all beings and holding them together in his providence, let him be condemned. (ND 627/1)

It is here, rather than in the texts of the ecumenical councils themselves, ${ }^{3}$ that we find the language of one God in three hypostases. One searches in vain even in the most significant Western contribution to the ecumenical councils, the Tome of Leo, for any identification of the One God with the Trinity.

In the introduction to Chapter 3 of Neuner-Dupuis, the editors give voice to the concern that presumably lies behind their failure to highlight the fact that the use of the language of One God is not the language of the ecumenical councils. They write:

In the patristic theology of the East the idea prevailed that the one God is God the Father, and that the Son and the Spirit share with him his divine life. This conception had the merit of being based on Scripture, but it could lend itself to misinterpretations. It could lead to subordinationist ideas which, in fact, did spring up in the East and came to a climax with the heresy of Arius. The other conception, prominent in the West, conceived God as the one divine substance, comprising Father, Son and Spirit. In this view, the unity of God and the equality of Father, Son and Spirit were easily safeguarded; but, the basic truth

${ }^{3}$ See Cubitt (2014) for reflection on the ecumenical quality of this synod. 
of the oneness of the divine nature could be misunderstood in such a way as to lead to the denial of the real distinction between the three persons. Modalism in its various forms did, in fact, deny this distinction. (Neuner and Dupuis 2001, 135-136).

Despite the obvious attempt at balance in this statement, the claim appears to be made that speaking of the "one God" as the Father, rather than as the Trinity, can lead to "subordinationist ideas." They also correctly make the point, however, that this identification of the one God with the Father has the merit of being based on Scripture. That being the case, it is not something that can be easily set aside, whatever the perceived risk of subordinationism.

Whatever the scriptural merit of the position here associated with the Eastern tradition, it is certain that a strict interpretation of Conciliar Trinitarianism would be bound to this tradition. It is true that the first 7 ecumenical councils emerged in the Eastern context, but they are recognized as ecumenical, rather than Eastern, councils. If it is true that there was a certain tendency to subordinationism in the patristic theology of the East, it is nevertheless also true that such subordinationism is explicitly overcome in the first and second ecumenical councils without any move away from the identification of the One God with the Father. Evidently, the opening line of the Symbols, where it is specifically stated that "one God, the Father almighty, maker of heaven and earth, of all things visible and invisible" is not subordinationist. The conclusion must be that the Symbols of the Faith proclaim both a belief in One God and in the Trinity of Father, Son and Holy Spirit. Since the anti-subordinationism of these councils cannot be doubted, we must conclude for Conciliar Trinitarianism, the claim that the One God is the Trinity is not necessary in order to avoid subordinationism. This cannot be simply ignored in Conciliar Trinitarianism.

I can deal more quickly with the remaining points in Neuner-Dupuis' summary. The next doctrinal point that the editors list is that the "three are one undivided Godhead". Obviously they have many texts to quote here, especially from the Western tradition: the Quicumque, Lateran IV, Lyons II, the Creed of Paul VI, Letter of Dionysius (262), Tome of Damasus (382), the Council of Toledo (675), the Council of Florence (Decree to the Copts, 1442), the first canon of Constantinople II (553), and the Lateran Synod (649). Of these, the most relevant to a Conciliar Trinitarianism is, once again, the first canon of Constantinople II, which speaks of "one nature or essence and one power and authority of Father and Son and Holy Spirit, a consubstantial Trinity, one Godhead worshipped in three hypostases or persons" (ND 620/1). This claim can therefore be taken as part of Conciliar Trinitarianism.

The next doctrinal point is that "Each person is fully God". Here there is no need to comment on the texts involved, since the intention of the Symbols of 


\section{DECLAN JOSEPH O'BYRNE}

Nicaea and Constantinople adequately establish this point, though they do not do so with precisely the words "fully God", preferring to find other ways to indicate that the Son and the Spirit are "consubstantial" with the Father, although this expression was adopted with some difficulty, and that the Spirit is Lord or "lordly" and is rightly co-worshipped and co-glorified with the Father and the Son. One curious point is that in their treatment of the subpoint that the Father is "fully God" the source Neuner-Dupuis offers is from the Eleventh Council of Toledo (675). One would have thought that this point is simply assumed, since the One God is said to be the Father in the Symbols, rooted - as we have seenin scriptural texts such as 1 Cor 8:6. Although this council would not be considered in a Conciliar Trinitarianism, I will quote this text because it helps reinforce a previous point:

We confess and believe that the holy and ineffable Trinity, Father, Son and Holy Spirit, is one God [unum Deum] by nature, of one substance, of one nature as also of one majesty and power.

And we profess that the Father is not begotten, not created, but unbegotten. For he himself, from whom the Son has received his birth and the Holy Spirit his procession, has his origin from no one. He is therefore the source and origin of the whole Godhead. He himself of his own essence is the Father, who in an ineffable way has begotten the Son from his ineffable substance. Yet he did not beget something different (aliud) from what he himself is: God has begotten God, light has begotten light. From him, therefore, is "all fatherhood in heaven and on earth" [cf. Eph 3:15 VulgJ.] (ND 308)

What is interesting here is the contrast with what we have already seen in Conciliar Trinitarianism as expressed by the Symbols of Nicaea and Constantinople. Toledo specifically states that the Trinity of Father, Son and Holy Spirit is one God by nature, of one substance etc. This is not in direct contradiction with the teaching that the one God is the Father, since Toledo is not saying that the "one God" is the Trinity, but rather that the Trinity is one God. Nevertheless, the point worth noting is that the Trinity here comes before the Father, such that the Father is treated as one of the persons of the Trinity, rather than as God himself. It is probably for this reason that the Neuner-Dupuis cite this text ${ }^{4}$ rather

${ }^{4}$ In their introductory comment on this council, the editors acknowledge that it was not a particularly important council. Here is what they write about the council: "small local Council, attended by only 17 bishops, has little significance today except for the beautiful confession of faith which was recited at its opening. The official value of this document consists in the fact that in subsequent centuries it was very highly regarded and considered a genuine expression of the 
than the Symbols of Nicaea and Constantinople on the full divinity of the Father.

Neuner-Dupuis next list two points that clearly are part of Conciliar Trinitarianism: that the Son is fully God and that the Holy Spirit is fully God. With the next teaching point, things are not so clear. This point is that the "divine persons are distinct from one another". On this point, no text approved by an ecumenical council is cited, even though the real distinction of the Father, Son and Holy Spirit is clearly presupposed by the councils. The same is true of the following point, namely that the three are distinct through mutual relationship. Here, the editors quote Toledo, Florence and Paul VI, but no ecumenical council can be cited. This claim, therefore, will not form part of Conciliar Trinitarianism, however much it is part of the shared traditions of East and West. Strictly speaking, Pawl's criteria would exclude points such as these, even though they are present in the theological discourse of the time of the ecumenical councils.

It is perhaps revealing that the point that the three of the Trinity are distinct through mutual relationship is listed prior to a collection of teachings that the editors list on the origins of the divine persons. The first subpoint here is that the Father is "absolute origin, from himself". It is not clear to me why no ecumenical council is cited here, since it would have been possible to claim that the idea that the Father is the absolute origin, from himself, is implicit in the teaching of all ecumenical councils, and indeed almost explicit in the teaching that the Father is the One God, who generates the Son and from whom the Holy Spirit proceeds. Perhaps the problem is similar to the one we encountered above on the fact that the Father is "fully God".

On the origin of the Son, instead, the editors summarize the point as follows: "The Son is born from the Father, from eternity". Here among the texts that they can quote from the ecumenical councils, they can clearly quote the Symbols of Nicaea and Constantinople. Looking at the issues surrounding those councils, the issue would seem to be especially related to the eternal generation of the Son, since that issue was particularly to the fore in the 4 th century debates. Here we are on extremely solid ground, as far as Conciliar Trinitarianism is concerned, and a great number of other conciliar texts could have been cited on this point.

Neuner-Dupuis then state that the Holy Spirit proceeds from the Father and the Son. Here, of course, the editors of Neuner-Dupuis, not having any ecumenical council to cite, fail to include any reference to the First Council of

Trinitarian faith; it is one of the important formulas of doctrine. In fact, hardly anywhere is the reflection of the early Church on the Trinitarian mystery and on Christ expressed with such precision and acumen as in this Creed which sums up the tradition of the earlier Councils and patristic theology of the West" (Neuner and Dupuis, 2001, 142-143). 
Constantinople's teaching that the Holy Spirit proceeds from the Father. Obviously, they do quote texts like the Quicumque, the Council of Toledo, the medieval councils of Lateran IV, Lyons and Florence, the Creed of Paul VI in support of the double procession, but nothing from the canon of Conciliar Trinitarianism following Pawl's criteria. The most interesting text that they list here, as far as Conciliar Trinitarianism is concerned, is the Vatican Clarification (i.e. the Pontifical Council for Promoting Christian Unity's document "Clarification on the Greek and Latin Traditions Regarding the Procession of the Holy Spirit", 1995). Even though they do not quote the teaching of Constantinople to the effect that the Holy Spirit proceeds from the Father, they do quote the indication of the Vatican Clarification that the Western teaching that the Spirit proceeds from the Father and the Son is not in contradiction with the teaching of Constantinople:

The Father alone is the principle without principle of the two other persons of the Trinity, the sole source (pege) of the Son and of the Holy Spirit. The Holy Spirit therefore takes his origin from the Father alone [...] in a principal, proper and immediate manner [....] The doctrine of the Filioque must be understood and presented by the Catholic Church in such a way that it cannot appear to contradict the Monarchy of the Father nor the fact that he is the sole origin (arche, aitia) of the ekporeusis of the Spirit. (ND 339)

The choice to not quote the Council of 381, but to quote the Vatican Clarification on the compatibility of the Western doctrine with that council, may be an oversight, but it appears to be a tendentious oversight, and in any case not relevant to Conciliar Trinitarianism as defined, which simply states that the Spirit proceeds from the Father.

On the point that the Holy Spirit is uncreated Love-Gift no ecumenical council is cited. Similarly, on the teaching that the divine persons are united through mutual indwelling no ecumenical council is cited. Having dealt with the origins of the divine persons, the editors of Neuner-Dupuis move to a number of points for which no ecumenical council can be cited. The first is that the divine actions in the world are common to the three persons.

The second subpoint is most important for the argument that I will present in the conclusion to this article. It is that the "The Trinitarian mystery is revealed in the mission of Son and Spirit for the salvation of human beings". The reference here is to a summary that the editors offer of the Second Vatican Council, with special reference to Lumen Gentium 2-4 and Ad Gentes 2-4. This is curious, since the texts quoted do not actually make the point that the missions of Son and Spirit reveal the Trinitarian mystery, and especially not the mystery of the Trinity in itself. The only reference to "revelation" is in Lumen Gentium 3, where there is reference to Christ revealing the mystery of the kingdom. 
The final point that the editors list in their summary of the church's teaching is a reference to the idea that these missions can be understood as God's selfcommunication. The reference here is to John Paul II's encyclical Dominum et Vivificantem (1986).

In his intimate life, "God is love" (1 Jn 4:8.16), the essential love shared by the three divine persons: personal love is the Holy Spirit of the Father and of the Son. Therefore he "searches even the depths of God" (1 Cor 2:10), as uncreated Love-Gift. It can be said that in the Holy Spirit the intimate life of the Triune God becomes totally gift, an exchange of mutual love between the divine persons, and that through the Holy Spirit God exists in the mode of gift. It is the Holy Spirit who is the personal expression of this self-giving, of this being-love. He is Person-Love. He is Person-Gift. Here we have an inexhaustible treasure of the reality and an inexpressible deepening of the concept of person in God, which only divine revelation makes known to us. (ND 337/10)

These final references to documents of the Second Vatican Council and to Dominum et Vivificantem make important reference to the idea of revelation, and specify a particular way of conceiving the relationship between the economy of salvation and the trinitarian mystery. There is a kind of passage from the economy of salvation to the trinitarian mystery, though this idea is not supported in the texts cited from Vatican II. ${ }^{5}$ The quotation from John Paul II manifests something of the same structure, with its development of the "intimate life" of God, which is the "essential love shared by the three divine persons", the "depths of God". In this quotation we also have the idea that "divine revelation" reveals the "concept of person in God." In these final references, a major structure of recent trinitarian thought, so obvious to many as to be taken as fundamental, emerges. This structure is that the "economic Trinity" reveals the "immanent Trinity", with the implication that the latter represents the privileged focus of trinitarian thought. When one penetrates from the economic to the immanent Trinity, according to this view, one reaches the proper place of inexhaustible treasure: the Trinity in itself.

\footnotetext{
${ }^{5}$ It is unclear why there is no reference to Dei Verbum. N. 2 states that "In His goodness and wisdom God chose to reveal Himself and to make known to us the hidden purpose of His will (see Eph. 1:9) by which through Christ, the Word made flesh, man might in the Holy Spirit have access to the Father and come to share in the divine nature (see Eph. 2:18; 2 Peter 1:4)". In the statement that God chose to reveal not just the hidden purpose of His will, but also Himself, one might find better support if one understands by "Himself" the Trinity. In the New Testament passages quoted, however, it is better I think to assume that it is God (the Father) who is intended, and is revealed through the missions of the Son and the Spirit.
} 
In brief, there is partial support for DT1 in Conciliar Trinitarianism. There is One God, and there is the Trinity of Father, Son and Holy Spirit, without the subordination of the Son and Spirit to the Father. Strictly speaking, Conciliar Trinitarianism does not support the idea that there is One God in three persons, nor any support for accounts of the inner life of the Trinity revealed by the economy of salvation. The reader of the documents of Conciliar Trinitarianism will not find the structure of the economic Trinity revealing the immanent Trinity, nor indeed the doctrine of the Trinity as One God in three persons. I do not mean, of course, that such developments are invalid or mistaken. I mean merely that one should be careful not to impose such later developments onto the reading of Conciliar Trinitarianism. Instead, what we find is something more closely resembling what I am calling DT2.

\section{DT2 and Conciliar Trinitarianism}

Let me begin by quickly recalling the outline formulation of DT2 that I offered in the introduction, which I propose as a better understanding of the content of Conciliar Trinitarianism. This was as follows: there is One God, the Father, and that the Son and the Holy Spirit share in the divinity of the One God in a nonsubordinationist way such that the Trinity of Father, Son and Holy Spirit are all rightly called God and together work in the economy of salvation that culminates in the Incarnation 6 and the outpouring of the Holy Spirit. This, being an outline, is obviously incomplete, but it will suffice to show that the flow of ideas is from claims about the Father, Son and Holy Spirit in themselves (theologhia) to claims about how the Father, Son and Holy Spirit act together in the economy of salvation (oikonomia). There is a distinction between the two kinds of discourse, but no suggestion that the latter reveals the former. It would be a lengthy task to document this approach exhaustively from the documents of Conciliar Trinitarianism, and there is not space to do so. I will take the Symbol of Constantinople (381), included among the documents approved at the Council of Chalcedon (451) as my primary example, and invite the reader to review the other documents of Conciliar Trinitarianism in the light of the suggestion I offer. I dedicate some space to the second article of the Symbol, regarding the Son and his Incarnation, since this is central preoccupation of the ecumenical councils, though for brevity I do not offer detailed documentation on individual claims.

\footnotetext{
${ }^{6}$ By "Incarnation" I do not mean the beginning of the human life of Jesus, but his whole human life, death, resurrection and ascension to the right hand of the Father as risen Lord, following the pattern of the Symbol of the Faith.
} 
There is no need to remind the reader that the structure of this Symbol, although it does not enter into speculation about the inner life of the Trinity, is nevertheless "trinitarian" in the sense that it speaks of the roles in the economy of Father, Son and Holy Spirit. The trinitarian structuring of statements of faith was common in Fourth Century controversies, but was not in itself a marker of trinitarian orthodoxy, since it is found in the teachings both of those supportive of the final pro-Nicene position and of those against that emerging position.

The Symbol of Constantinople speaks first of the One God who is the Father Almighty, maker of heaven and earth, of all things visible and invisible. There is no expansion here of the role of the Father in the economy of salvation, but this role is implicit in what the Symbol later says about the generation of the Son and the "spiration" of the Spirit (the Symbol does not offer a verb to speak of the production of the Holy Spirit), and is then completed in what is said about the "missions" (again the Symbol does not reach the level of abstraction that would require a single word for what the Son and the Spirit do in the economy). The Father is the One God who is origin, both of the eternal being of the Son and the Spirit and of what they do in the economy of salvation. Such claims are implicit rather than explicit, and the short formulation of belief in the Father indicates a kind of apophatic reserve with regard to the Father's role, such that the balance of this Symbol of language about the Father in relation to the Son and the Spirit approximates to that of the New Testament, where the Son's role commands most attention, the Spirit's role is second, and while God's role is at the origin of everything, it is the one that attracts least direct comment.

The Symbol then speaks of the Son, and the treatment of the Son may be divided into two discrete parts. The first part regards who the Son is in relation to the Father, and it reflects the outcome of the disputes of the Fourth Century, and as such is often regarded in recent trinitarian theology as evidence of a kind of breakthrough the result of which was the so-called formulation of the "doctrine of the Trinity" (understood as DT1). Thus, from a certain point of view, the novelty of this Fourth Century development lies in the clear exclusion of any the kinds of subordinationism that had been assumed in earlier Logos christology theological discourse. The key arguments leading to the exclusion of the such subordinationism were, it seems to me, the defence of the fact that the God is eternally Father, and therefore must eternally have a Son. Irrespective of hypotheses about the reasons for this breakthrough, the point that for my argument is crucial is that the importance of the second article of the Symbol is not confined to what it says about the eternal relation of the Son to the Father.

The second part of the second article of the Symbol of Constantinople, closely reflecting and expanding on that of Nicaea, however, also contains something of crucial interest to Conciliar Trinitarianism (understood as DT2, now, rather than as DT1). It is introduced by the important formulation "For us and for our 
salvation". This represents the passage from the part related to the Son in relation to the Father to the part related to the Son's work in the economy. It begins, obviously, from his incarnation through the work of the Holy Spirit, his crucifixion, suffering, death and burial, his resurrection and ascension to the right hand of the Father, his future coming and the claim that his Kingdom will be without end.7 Although this part of the Symbol is not generally given detailed consideration in trinitarian theology, since it seems to be traditional and uncontroversial material, it does come to represent the key question in the socalled "Christological controversy" beginning in the 5th century. The debate between Nestorius and Cyril revolves around whether Christ is himself the second person of the Trinity such that it is the divine Son himself, the one identified as being consubstantial with the Father is, however, startlingly new compared with traditional formulations. In the light of the exclusion of the kind of subordinationism condemned at Nicaea, the claim is now that the Son who is himself consubstantial with the Father became a creature, and lived a fully human life. For Nestorius, this was too much. If the Son is truly divine, he could not himself be said to be born of a human mother, suffer and die. Nestorius' interpretation of the trinitarian teaching leads him to rule out the personal identity of the Son and Christ. For Cyril, instead, the belief of the church, however surprising, is that the Son who is consubstantial with the Father does himself truly become human. It is the interpretation of this second part of the second article of the creed that is in focus at the Council of Ephesus. ${ }^{8}$

There is no good reason to claim that this is not relevant to Conciliar Trinitarianism since the question touches on claims about one of the Trinity. To claim that the Nestorian controversy is "christological" rather than "trinitarian" only holds up if one assumes that the word "trinitarian" only applies to DT1, the doctrine of One God in three persons. But the ecumenical councils are not concerned with a doctrine of the Trinity in abstraction from the economy, such that the latter is revealed by the former. When we take the ecumenical councils together we do find something like the distinction between the "economic Trinity" and the "immanent Trinity" in the distinction between theologhia and oikonomia, but this does not function as it does in most recent theology. The issue underlying the whole controversy from Ephesus onwards is whether what is said about the human life of Jesus should be directly attributed to the human nature

\footnotetext{
${ }^{7}$ For an interesting comment on the relation between the Creeds and the gospels see (Wright 2016). It seems important to state that the Symbol of the Faith was never intended as a substitute for the gospel.

${ }^{8}$ It is the interpretation of the second article of the Symbol of Nicaea that is in focus in the letters of Nestorius to Cyril, and of Cyril to Nestorius that were examined at Ephesus.
} 
of Jesus (the position embraced by Nestorius), the divine nature (a position excluded by both Nestorius and Cyril), or to the divine person of the Son (the position embraced by Cyril and the Council of Ephesus, 431). The Son in question, it should be clear, is the Eternal Son himself, the Second Person of the Trinity. Nestorius found it necessary to prise discourse about the eternal identity of the Son apart from discourse about the human life of Jesus. His denial of the title Theotokos, and the Cyrillian claim that it is the divine Son himself who suffers and dies, amounts to a separation of trinitarian discourse from discourse about Christ. The Council of Ephesus denies the validity of such a separation and approves claims about the personal identity of the Eternal Son and Jesus who is born of Mary and who dies on the cross. Nestorius fails to make the step from theologhia to oikonomia successfully, believing that the divinity of the Son rules out his direct personal involvement in the economy. Conciliar Trinitarianism, following Cyril, defends the involvement of the whole Trinity in the Christ event: Jesus is the eternal Son of the Father made incarnate by the power of the Holy Spirit. ${ }^{9}$ The councils continue to hold this line against a variety of attempts to attenuate the power and paradoxical character of the claim, against Nestorius, against Eutyches who denies the consubstantiality of the Eternal Son made flesh with human beings, against Nestorianizing interpretations of Chalcedon, and against the denial of a human activity and will in Jesus. In terms of a descending theology, Conciliar Trinitarianism culminates in Canon 10 of the Council of 553: "If anyone does not confess that he who was crucified in the flesh, our Lord Jesus Christ, is true God, Lord of glory and one of the Holy Trinity, anathema sit" (ND 620/10). In terms of an ascending theology, Conciliar Trinitarianism culminates in the proclamation of the human will in Jesus as the human will of one of the

\footnotetext{
${ }^{9}$ The role of the Holy Spirit in the life of Jesus is not fully expressed in the documents of the ecumenical councils, but is not absent. There are multiple reference to the conception of Jesus by the power of the Spirit. In the 9th of Cyril's Twelve Anathemas, read at the Council of Ephesus and officially recognized at the Council of 553, we read: "If anyone says that the one Lord Jesus Christ was glorified by the Spirit, implying that through him he had access to a power that was not his own, and that he received from the Spirit the power to overcome unclean spirits and to work divine signs among us, and does not rather say that he performed divine signs by virtue of the Spirit which was his own, anathema sit". In canon 12 of the Council of 553, against positions of Theodore of Mopsuestia, it is maintained that Christ truly gives the Spirit. The reluctance to give extensive treatment to the Holy Spirit's role in the life of Jesus is explained partly by the fact that it was not the direct object of debate, and partly by the concern that Christ's relationship with the Spirit might misunderstood on an analogy with the prophets who received the Spirit. The point that they wished to defend was that the Spirit was his own, and not any denial that in his humanity he received and was guided by the Spirit. On the background to this question see (Keating, 1999). For a systematic treatment see (Coffey 2011).
} 
Trinity:

Therefore, preserving entirely what is neither fused not divided, we proclaim that the entire matter is this concise utterance: believing that one of the Holy Trinity, who after the incarnation is our Lord Jesus Christ, is our true God, we say that his two natures shine forth in his one hypostasis. In it, throughout his entire human existence in the flesh, he made manifest his miracles and his sufferings, not in mere appearance but in reality. (ND 637)

It is precisely in this insistence that one of the Holy Trinity is fully human, "not in mere appearance but in reality" that we uncover the heart of Conciliar Trinitarianism. The doctrine of the Trinity culminates here: in the claim that one of the Trinity has become fully human by the work of the Holy Spirit, and lives a fully human life, returning as human being to the Father in the resurrection and ascension. The centrality of person rather than nature is confirmed at Nicaea II, when it extends the question to the veneration of images, where the veneration is directed at the person imaged (ND 1252).

Returning briefly to the Symbol of Constantinople (381) before drawing this reflection to a close, we should note that the article on the Holy Spirit too manifests the same tendency to state theological and economic claims about the Holy Spirit together, with the effect that the theological claims find their completion in economic claims. Thus, while it is true that the Holy Spirit is understood to be divine and not one of the creatures, the language adopted emphasizes the role of the Holy Spirit in the economy of salvation. Thus, the Symbol says that he proceeds from the Father, and this should be taken as a theological claim, but also that he is Lord and giver of life, and this is said primarily not in relation to the Father and the Son, but in relation to creatures. Similarly, he is "worshipped and glorified" by creatures, and has spoken (to creatures, not to the Father and the Son), through the prophets. The Symbol had already spoken of the role of the Holy Spirit in the Incarnation of the Son. The fruit of the operation of the Holy Spirit is the one Holy Catholic and apostolic Church, baptism, the forgiveness of sins, the resurrection of the dead and the life of the world to come.

Here too, as with the article on the Son, it is the implicit canons of modern trinitarian thought that tend towards a separation of claims about the divinity of the Holy Spirit in himself from claims about the Holy Spirit's roles in the economy of salvation. In the Symbol the two are distinguishable, but immediately coordinated. The emphasis in Conciliar Trinitarianism remains on the economic work of the Spirit, as it had been the case with that of the Son. In the logic of Conciliar Trinitarianism, it is necessary to defend the true divinity of the Holy Spirit, as it was necessary to defend the true divinity of the Son, because only if the second and third divine persons are recognized as truly God can they 
fulfil their functions in the economy of salvation.

\section{Conclusion}

I have argued that DT1 is not an adequate statement of Conciliar Trinitarianism. This does not mean that it is not true. Nor does the claim that DT2 is a better statement of Conciliar Trinitarianism mean that one should not develop speculative accounts of the inner life of the Trinity, theories of persons, relations, perichoresis and so on. I see no reason why the shape of Conciliar Trinitarianism need be the only, or final, form of trinitarianism. The fact that patristic and scholastic theologians have developed reflections developing precisely such theories without finding themselves in contradiction of the ecumenical councils shows that not only are such developments possible, but have in fact emerged and have asserted their importance for trinitarian theology. Indeed, many of them have made their way into magisterial teaching, as the collection of teachings presented by the editors of Neuner-Dupuis makes clear.

Nevertheless, it is not helpful to impose such developments on our reconstruction of Conciliar Trinitarianism. ${ }^{10}$ The obvious question arises: what is the precise relation of Conciliar Trinitarianism to DT1, namely theological discourse on the Trinity apart from the economy of salvation, but I will not develop this point here. Instead, in closing, I would like to briefly set out one way of expressing the contrast between DT1 in its contemporary form, and Conciliar Trinitarianism understood as expressing DT2. It hinges on a certain interpretation of the role of revelation, which - as we have seen in our comments on Neuner-Dupuis' summary of the Second Vatican Council and Dominum et Vivificantem - approaches the question of the relation of the economy of salvation to the doctrine of the Trinity (DT1) by means of the idea that the former reveals the latter. In contrast, DT2 suggests that the economy of salvation is something more than what is implied in the discourse on the Trinity in se, such that what is revealed is not just what the Trinity is in itself, but also what the Trinity has brought about "for us and for our salvation".

Contemporary theology has struggled with the question of the relevance of the doctrine of the Trinity, but has tended not to recognize that the issue is most simply resolved by shifting our attention from DT1 to DT2. To speak of the relevance of the doctrine of the Trinity does not necessarily mean the relevance of the doctrine that there is One God in three persons. Again, this does not mean

10 Brian Daley has worked consistently on the relations between the doctrines of the Trinity and the doctrine of Christ in the patristic period. See, for example, (Daley 2007). 
that DT1 is irrelevant. It simply means that the relevance of DT1 is established when properly coordinated with DT2: our discourse about the Trinity in se becomes relevant when it aliments discourse about the Trinity pro nobis. To argue with Nestorius that the Son is consubstantial with the Father, a "trinitarian" claim as far as the standard view is concerned, is insufficient. From the point of view of DT1, Nestorius is probably orthodox, but not from the point of view of DT2. Neither is the Chalcedonian teaching that Christ is consubstantial with the Father as to the divinity, and consubstantial with us as to his humanity sufficient, if that claim is understood in a Nestorianizing way. It is essential that we make it clear that the Christ is the divine Son, one of the Trinity, and accept all of the paradoxes that flow from his Incarnation: the Creator has become creature, the invisible has become visible, the immutable has become mutable, the impassible has become passible and so on.

This implies an inversion in the direction of the logic of theological argumentation about the "economic" and the "immanent" Trinity. The standard view is that the "economic Trinity" reveals the Trinity, yielding DT1. Thus, we might say that the life of Jesus culminating in the event of the cross, reveals the eternal relationship of the Son to the Father. This remains true. But the standard view, however, can also suggest that the economy also reveals something about divinity itself and the attributes of divinity, on the assumption that that economic Trinity is a point of departure that serves to reveal the Trinity in itself.

Thus, the tendency is to think that the event of the cross if taken seriously should lead us to attenuate or even reject claims about divine impassibility. In practice, if we take revelation as our prime category, we may feel obliged to say that the suffering of Jesus on the cross reveals that there is something corresponding to suffering in the Trinity. This might be true, since we can say that what is suffering in the economy corresponds to divine intratrinitarian love in the "immanent Trinity." It only complicates matters, however, if we attempt to claim on this basis that suffering as love, or if we abandon the idea of divine impassibility. The teaching of the councils is simpler: it does not require us to change the meaning of suffering such that suffering is revealed to be love, that the suffering of Christ reveals that in the Trinity there is something like, but also unlike, suffering. Rather, the teaching is that the Son who is divine and therefore impassible in himself has become passible for us. What the Son becomes does not reveal what he is in himself, but what he has become economically. Thus with all of the other attributes: the visibility of Christ does not reveal a kind of visibility of the Eternal Son, the growth in wisdom and age of Christ does not reveal a kind of growth in wisdom and age of the Eternal Son and so on. The non-confusion of natures taught by Chalcedon means that just as divinity and humanity are not mixed or confused, so too the impassibility of the divine nature is not confused with the passibility of the human nature, invisibility with visibility, 
immmutability with mutability and so on. What holds the two sets of contraries together is the hypostatic union, the person of the Son, who is both divine and human. Discourse on Christ is discourse on what the Son has become in the economy of salvation, for us and for our salvation, and not the revelation of hitherto unsuspected creaturely attributes of the divinity. Similarly, discourse on the Holy Spirit speaking through the prophets is not understood as a revelation of the eternal function of the Holy Spirit within the Trinity.

Conciliar Trinitarianism (understood as DT2) relates what happens in the economy to what is true in the Trinity prescinding from the economy, according to a scheme where the humanity of Jesus does not reveal the divinity of the Son, but the Son himself; not the nature, but the person. ${ }^{11}$ It is his humanity, rather than directly his divinity that is of interest: what Jesus reveals is human nature in the mode of sonship, rather than his own divine nature. Divine sonship, not divine nature. In Jesus, human suffering is transformed into love. The discourse of Conciliar Trinitarianism certainly defends the divinity of the Son, but places the person of the Son and his true humanity at the centre of the action. The event of the cross is a trinitarian act: one of the Trinity (the Son) is sent by the Father in the power of the Spirit, and lives a human life in the power of the Spirit, in obedience to the Father, suffers and dies. The Father then raises him in the power of the Spirit to eternal life. This economy is not the revelation of what is eternally true of God in Godself, but the salvific act of the Trinity acting economically in a new way. Conciliar Trinitarianism is concerned with this doctrine of the Trinity (DT2), rather than any direct account of the relations of the Father, Son and Holy Spirit apart from the economy of salvation (DT1). The ecumenical councils do contain elements that are essential to DT1, but the trinitarianism of the ecumenical councils themselves is such that statements about the Trinity in itself ground an economic trinitarianism. ${ }^{12}$

11 This is not obvious to all scholars. A recent work that systematically fails to distinguish between the function of person and nature is (Crisp 2016). A recently published which makes important use of the distinction is the similarly entitled (McFarland 2019).

12 David Coffey is strong on this point: his reworking of the terms of Rahner's Grundaxiom, which speaks of a biblical Trinity, an immanent Trinity and an economic Trinity points substantially in the same direction as this article. See especially (Coffey 1999). For Coffey, the standard appropriation of Rahner's Grundaxiom leads to the idea that one moves from the economic Trinity to the immanent Trinity. Instead, he believes that the biblical data lead to reflection on the Trinity in itself (the "immanent Trinity"), but that the acquisitions on the level of the who the Son and the Spirit are eternally leads to a new and richer understanding of the biblical data. It is one thing to say that a man died on the cross, but another to say that one of the Trinity became human and died on the cross. This second statement, for Coffey, would be 


\section{Bibliography}

Coffey, David. 1999. Deus Trinitas: The Doctrine of the Triune God. New York: Oxford University Press.

Coffey, David. 2011. Grace: The Gift of Holy Spirit. Milwaukee: Marquette University Press.

Crisp, Oliver D. 2016. Word Enfleshed: Exploring the Person and Work of Christ. Ada, MI: Baker Academic.

Cubitt, Catherine. 2014. The Lateran Council of 649 as an Ecumenical Council. In The Acts of the Lateran Synod of 649, eds. Richard Price, and Mary Whitby, 61, 133-147. Liverpool: University Press. https://doi.org/10.5949/UPO9781846314513.009.

Daley, Brian. 2007. The persons in God and the person of Christ in Patristic theology: an argument for parallel development. In The Mystery of the Holy Trinity in the Fathers of the Church, eds. Vincent Twomey, and Lewis Ayres, 936. Dublin: Four Courts Press

Keating, Daniel A. 1999. The Baptism of Jesus in Cyril of Alexandria: The Recreation of the Human Race'. Pro Ecclesia 8, 201-222. https://doi.org/10.1177/106385129900800207.

McFarland, Ian A. 2019. The Word Made Flesh: A Theology of the Incarnation. Westminster John Knox Press.

2001. The Christian Faith: Doctrinal Documents of the Catholic Church. Edited by Josef Neuner, and Jacques Dupuis. New York: Alba House.

O'Byrne, Declan. 2010. Spirit Christology and Trinity in the Theology of David Coffey. Oxford: Peter Lang.

Pawl, Timothy. 2016. In Defense of Conciliar Christology: A Philosophical Essay. Oxford Studies in Analytic Theology. Oxford: OUP. https://doi.org/10.1093/acprof:oso/9780198765929.001.0001.

Wright, N. T. 2016. How God Became King: The Forgotten Story of the Gospels. New York: HarperOne.

Published Online: January 16, 2020

economic trinitarianism. He writes: “The economic Trinity [...] is the integration of the immanent Trinity with the biblical data, and this entails a return [...] Thus the Son in the economic Trinity is the eternal Logos become man, or human, in the Jesus of Nazareth of the gospels, a figure not identical, in description at least, with the Son of either the biblical or the immanent Trinity. And something similar can be said of the Holy Spirit and the Father as well" (Coffey 1999, 16). For a general introduction to David Coffey's theology of the Trinity and the articulation of the same with his Spirit Christology see (O'Byrne 2010). 